\title{
The epithelial cholinergic system of the airways
}

\author{
W. Kummer $\cdot$ K. S. Lips $\cdot$ U. Pfeil
}

Accepted: 29 May 2008 / Published online: 20 June 2008

(C) Springer-Verlag 2008

\begin{abstract}
Acetylcholine (ACh), a classical transmitter of parasympathetic nerve fibres in the airways, is also synthesized by a large number of non-neuronal cells, including airway surface epithelial cells. Strongest expression of cholinergic traits is observed in neuroendocrine and brush cells but other epithelial cell types-ciliated, basal and secretory-are cholinergic as well. There is cell type-specific expression of the molecular pathways of ACh release, including both the vesicular storage and exocytotic release known from neurons, and transmembrane release from the cytosol via organic cation transporters. The subcellular distribution of the ACh release machineries suggests luminal release from ciliated and secretory cells, and basolateral release from neuroendocrine cells. The scenario as known so far strongly suggests a local auto-/paracrine role of epithelial ACh in regulating various aspects on the innate mucosal defence mechanisms, including mucociliary clearance, regulation of macrophage function and modulation of sensory nerve fibre activity. The proliferative effects of ACh gain importance in recently identified ACh receptor disorders conferring susceptibility to lung cancer. The cell type-specific molecular diversity of the epithelial ACh synthesis and release machinery implies that it is differently regulated than neuronal $\mathrm{ACh}$ release and can be specifically targeted by appropriate drugs.
\end{abstract}

W. Kummer $(\bowtie) \cdot$ K. S. Lips $\cdot$ U. Pfeil

Institute for Anatomy and Cell Biology,

Excellence Cluster Cardiopulmonary System,

Justus-Liebig-University Giessen, 35385 Giessen, Germany

e-mail: wolfgang.kummer@anatomie.med.uni-giessen.de

Present Address:

K. S. Lips

Department of Trauma Surgery,

University Hospital of Giessen-Marburg,

Justus-Liebig-University, 35385 Giessen, Germany
Keywords Acetylcholine - Airway epithelium · Brush cell $\cdot$ Neuroendocrine cell

\section{Introduction}

Acetylcholine (ACh) is a major regulator of airway function. In particular, it is one of the strongest known bronchoconstrictors and stimulators of secretion, but it is also involved in regulating less acute mechanisms such as airway wall remodelling in disease and immunomodulation (Gosens et al. 2004; Kummer and Lips 2006) (Fig. 1). Accordingly, pharmacological manipulation of cholinergic signalling, mostly inhibition, is a keystone in treatment of common lung diseases, for example chronic obstructive pulmonary disease (COPD) (Belmonte 2005; Gosens et al. 2006). The classical view on ACh in the respiratory system is that of a neurotransmitter being released from parasympathetic nerve fibres that innervate airway smooth muscle and glands. In addition, however, many non-neuronal cells are capable of ACh synthesis and release, including such diverse cell types such as keratinocytes, lymphocytes, placental trophoblast, endothelial cells and many more (for reviews, see Wessler et al. 1998, 2001b). Non-neuronal $\mathrm{ACh}$ is also present in the airway epithelium (Klapproth et al. 1997; Proskocil et al. 2004; Kummer et al. 2006) where it is believed to regulate cell proliferation (Metzen et al. 2003) and to contribute to pathomechanisms underlying COPD (Barnes 2004). Here, the pathways and mechanisms of ACh synthesis, release, action and its termination in the airway epithelium are reviewed. Particular emphasis is given to highly cell type-specific modifications of these mechanisms that potentially may allow to addressing selectively non-neuronal and neuronal cholinergic signalling by pharmacological intervention. Beforehand, a short over- 


\section{Airway epithelium}

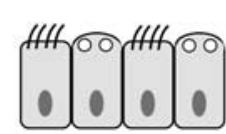

Proliferation

Mucous secretion

Cl-Secretion

GM-CSF release

IL-8 release

Ciliary beat frequency

Fibroblast

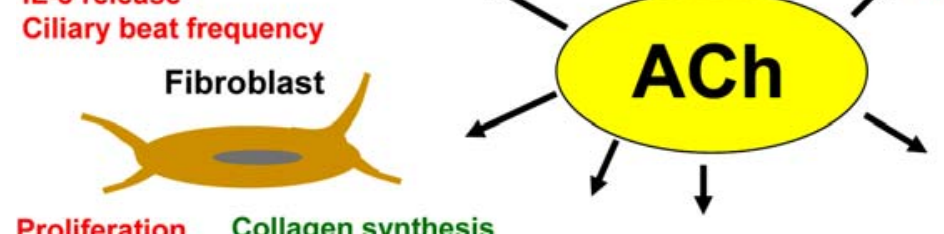

Proliferation Collagen synthesis

IL-8 release Myofibroblast

MMP-2 release transdifferentiation

Collagen

synthesis

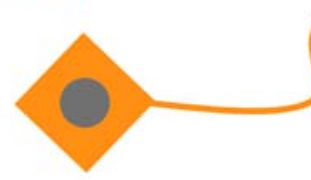

Cholinergic neuron

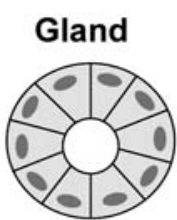

Secretion
Constriction Relaxation

Contractile protein expression

Synergistic induction of mitogenesis

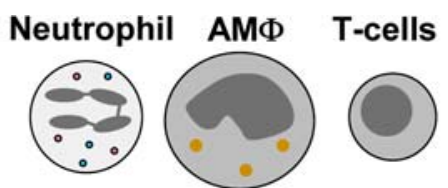

Pro-inflammatory

Cytolytic T-cell differentiation

LTB4 release

Neutrophil

chemotactic activity
Anti-inflammatory

TNF $\alpha$ and IL-1 $\beta$

release \

Thromboxane

synthase \

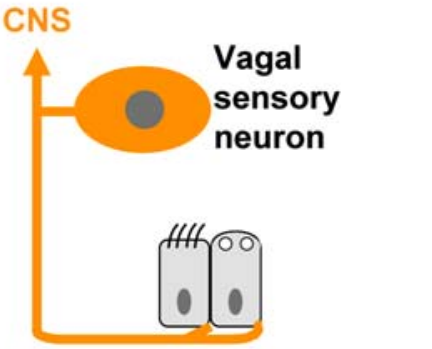

Fig. 1 Spectrum of actions of acetylcholine $(A C h)$ in the airways. In cases where ACh may cause opposing effects, dependent on receptor subtype being involved, the term is written both in green and red colour

view on airway epithelial cell types and neural and nonneuronal ACh handling will be presented that is required for understanding of the cell type-specific variants and their potential meaning.

\section{Tracheal and bronchial surface epithelial cell types}

Altogether, at least 12 types of epithelial cells on the airway surface and five types of epithelial cells in the airway glands have been described, although some of these represent differentiating or intermediate cells or are not recognizable in all species (Robbins and Rennart 1997). Here, we concentrate on the major surface epithelial cells. The hallmark of the respiratory epithelium is the ciliated cell that generates the driving forces for mucociliary clearance, that is cleaning of the airway surface from inhaled particles by transporting a mucous layer towards the larynx. Ciliated cells make up between 32 and $55 \%$ of total tracheal epithelial cells in ten different mammalian species (Pavelka et al. 1976), with higher relative numbers on the epithelial surface at the tracheal ligaments (rat: 65\%) and lower frequency (rat: $32 \%$ ) overlying cartilage rings (Oliveira et al. 2003). With rather little species variation, these ciliated cells are columnar in the trachea and large bronchi (approx- (e.g. collagen synthesis by fibroblasts). Adopted and extended from Kummer and Lips (2006), incorporating recent findings by Profita et al. (2008) and Haag et al. (2008)

imately $20 \mu \mathrm{m}$ long and $7 \mu \mathrm{m}$ wide, tapering to $2 \mu \mathrm{m}$ at the basement membrane) and then decrease in height towards small bronchi and bronchioli (Lee and Forrest 1997). Besides their characteristic beating cilia ( $6 \mu \mathrm{m}$ in length, 100-250 per cell), they also protrude microvilli $(1.8 \times 0.1 \mu \mathrm{m})$ into the lumen (Hansell and Moretti 1969). Their surface compartment contains the cystic fibrosis transmembrane conductance regulator (CFTR) protein, whose mutation causes the common inherited disease cystic fibrosis (CF) (Puchelle et al. 1992). In the mouse, a species with a general paucity of submucosal glands, expression of human CFTR in ciliated cells of $\mathrm{CFTR}^{-1-}$ mice is capable of correcting the airway defects in $\mathrm{Cl}^{-}$secretion and $\mathrm{Na}^{+}$ absorption (Ostrowski et al. 2007). In species such as pig and human, where submucosal glands are present in significant numbers, it is assumed that the bulk of the luminal periciliary fluid originates from these glands and ciliated cells modify its ionic composition (Wu et al. 2007).

The carbohydrate-rich glycoproteins ("mucins") and lipids of the mucous layer are produced by submucosal glands and, particularly in species with low numbers of such glands, the second major surface epithelial cell type, broadly designated "non-ciliated cells". Their relative number, structure and secretory products change along the tracheobronchial tree within a species, and among the tracheas 
between species according to tracheal diameter. Classical goblet cells account for $9 \%$ in the human trachea and are practically absent from human distal bronchioli and mouse trachea (Pavelka et al. 1976). Smaller airways such as human bronchioli and mouse trachea contain cells with protruding apical region decorated with few microvilli, abundant smooth or rough (dependent on species) endoplasmic reticulum, and secretory granules smaller than those found in goblet cells (Pavelka et al. 1976; Plopper et al. 1980). In distal airways, they are often referred to as Clara cells, in the trachea of small mammals such non-ciliated cells have also been termed secretory cells or mucous cells. Certainly, these cells do not comprise a homogenous population. In the present review, however, they will be collectively referred to as "secretory cells" since no distinction between subtypes has so far been made with respect to reports on epithelial ACh synthesis or action.

Basal cells, not facing the lumen, are found in larger airways only and account for 20\% (mouse, hamster)-32\% (horse, human) of tracheal epithelia cells (Pavelka et al. 1976).

Besides these most frequent cell types, there are specialized epithelial cells rather infrequent in number but particularly conspicuous in their expression of cholinergic traits. Pulmonary neuroendocrine cells develop from a different group of precursors than those forming the peripheral sub- set of respiratory epithelial cells (Perl et al. 2002). They either occur solitarily within the airway epithelium (Fig. 2a), or are clustered as neuroepithelial bodies (NEBs) preferentially at bronchial branchings (Linnoila 2006). Their development is differentially controlled since targeted disruption of NeuroD, a proneural bHLH factor, results in an increased number of NEBs but a reduced number of solitary pulmonary neuroendocrine cells in the neonatal mouse lung (Neptune et al. 2008). They share the presence of dense core granules that store bioactive amines and neuropeptides and are located in the basal compartment (Fig. 2c). NEBs are present in great numbers before birth and during the neonatal period and are generally believed to contribute to lung maturation, and to function as oxygen sensors complementing the maturing carotid body (Linnoila 2006). The oxygen sensor function, however, has also been questioned and the idea has been posed that the different populations of myelinated vagal afferents that selectively innervate intraepithelial pulmonary NEBs may represent subpopulations of the extensive group of known electrophysiologically characterized myelinated mechanosensitive vagal airway receptors (Adriaensen et al. 2006). The role of solitary pulmonary neuroendocrine cells is also not fully clear. Proposed roles in fetal and newborn lung development include regulation of branching morphogenesis as well as cellular growth and maturation. In adult mice, they are associated
Fig. 2 Ultrastructure of neuroendocrine $(E)$ and brush $(B)$ cells in the mouse trachea. a An endocrine cell is situated next to a secretory $(S)$ and ciliated $(C)$ cell. Its apical microvilli are less densely packed than those of a brush cell ( $\mathrm{B}$ in b). c Endocrine cells are characterized by large (ca. $100 \mathrm{~nm}$ ) dense-core granules in their basal cytoplasma; $M$ mitochondrium. $\mathbf{d}$ In brush cells, filament bundles $(F)$ extend from the bundle of microvilli into the apical cytoplasm. The cytoplasm is rich in tubulovesicular structures which currently have not been fully characterized
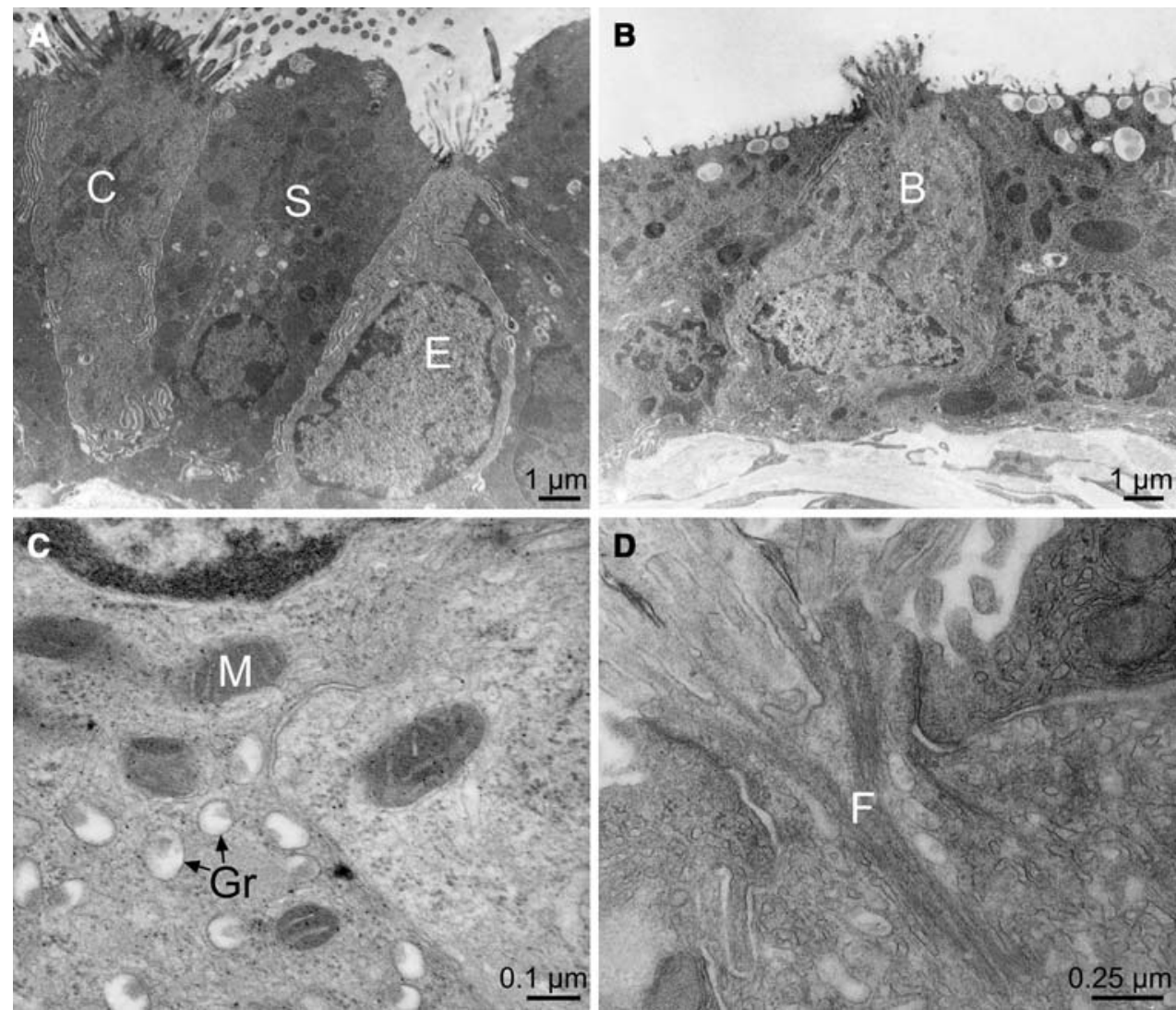
with stem cell niches in both the proximal and distal airways, and it has been proposed that they foster a microenvironment resistant to destruction of environmental agents and promoting stem cell renewal (Linnoila 2006). Clinically important, pulmonary neuroendocrine cells can give rise to a malignant tumour, the small cell lung carcinoma (Linnoila 2006).

Finally, an equally infrequent cell type is characterized by an apical brush of microvilli (Fig. 2b, d) and, accordingly, termed "brush cell". Tracheobronchial brush cells express components of the taste-signalling cascade and, consequently, are considered to act as chemosensory cells (Kaske et al. 2007; Merigo et al. 2007; Osculati et al. 2007). The interesting hypothesis has been posed that they may sense bacterial colonization and serve to initiate defence mechanisms (Sbarbati and Osculati 2006).

\section{ACh synthesis and recycling in cholinergic nerve fibres}

The cation ACh is synthesized in the axoplasm by choline acetyltransferase (ChAT) from choline and acetyl-CoA being generated in mitochondria (Fig. 3). To allow for ACh synthesis sufficient for synaptic transmission, the essential nutrient choline has to be taken up from the extracellular space. This uptake is the rate-limiting step in neuronal ACh synthesis and it is achieved by a high-affinity choline transporter (CHT1) that has been cloned and is pharmacologically characterized by its sensitivity to hemicholinium-3 and dependency on sodium (Okuda et al. 2000; Apparsundaram et al. 2001). Once being generated in the axoplasm, ACh is translocated into small (about $45 \mathrm{~nm}$ in diameter) synaptic vesicles via the vesicular acetylcholine transporter (VAChT), a 12 transmembrane domain protein acting as a $\mathrm{H}^{+} / \mathrm{ACh}$ exchanger (Parsons 2000). The interior of these vesicles binds up to 10,000 molecules of ACh via a matrix enriched with the synaptic vesicle proteoglycan SV2 (Reigada et al. 2003). Depolarization of the nerve terminal triggers exocytotic release of ACh from these vesicles, during which the "smart gel matrix" of the vesicles releases neurotransmitter and changes its volume when challenged with small ionic concentration change (Reigada et al. 2003; González-Sistal et al. 2007). Extracellular ACh acts via two classes of cholinergic receptors: Metabotropic muscarinic receptors (MR, five isotypes are known: M1-M5) are G protein-coupled receptors with seven transmembrane domains, and ionotropic nicotinic acetylcholine receptors (nAChR) are cation channels with two ACh binding sites, being formed as hetero- or homopentamers consisting of a high diversity of subunits (Lukas et al. 1999; Wess et al. 2007). The action of ACh is rapidly terminated and spatially limited by cleavage into acetate and choline through the extremely efficient enzyme, ACh esterase (AChE). This enzyme is synthesized by cholinergic neurons themselves thereby ensuring that the localization of neuronal $\mathrm{ACh}$ release matches that of ACh degrading capacity. Choline is taken up again at the nerve terminal via $\mathrm{CHT} 1$, and a new cycle of ACh synthesis and release is to begin (Fig. 3).

\section{ACh synthesis and recycling in non-neuronal cells}

Phylogenetically, non-neuronal ACh synthesis is the older system, as it can be found already in bacteria and plants (Wessler et al. 1999). Some of the particularly efficient enzymes and transporters of cholinergic neurons have evolved comparatively recently and are not found throughout the non-neuronal cholinergic system. Instead, less efficient mechanisms of ACh synthesis, storage and release dominate, although not exclusively (Fig. 4). So, each cell does contain uptake mechanisms for choline which are indeed necessary for cellular survival because of the need of choline for synthesis of plasma membrane lipids, in particular phosphatidylcholine. There is a great variety of plasma membrane choline transporters (Michel et al. 2006), and only few cholinergic non-neuronal cells do express the high-affinity choline transporter CHT1 (e.g. Pfeil et al. 2003). An alternative route for ACh synthesis is provided by carnitine acetyltransferase (CarAT) which, albeit in principle less efficient than ChAT, drives ACh synthesis in skeletal muscle fibres (Tucek 1982) and is present in the urothelium where $\mathrm{ACh}$ is found in absence of ChAT

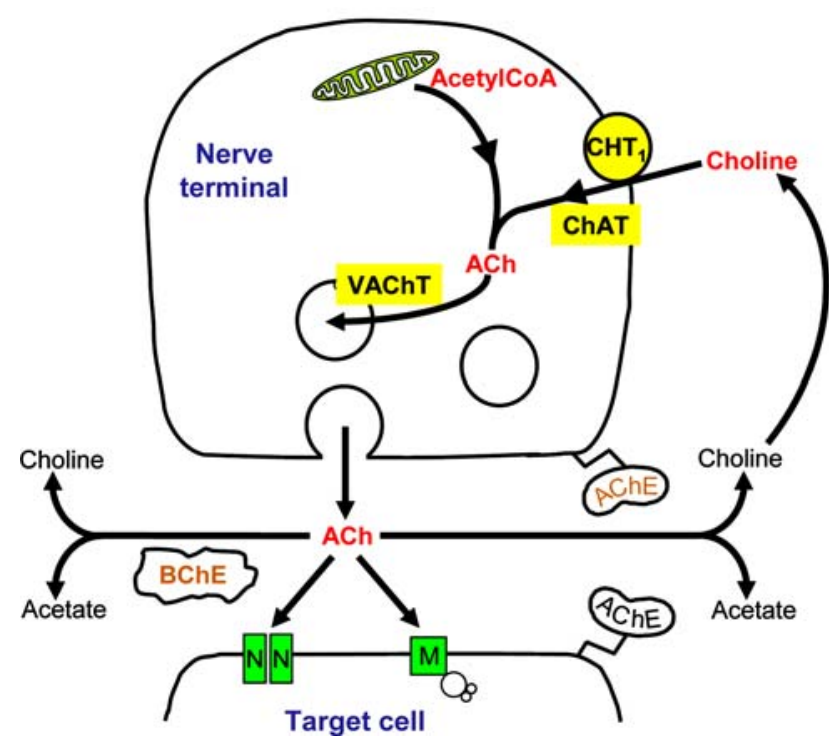

Fig. 3 Recycling pathway of acetylcholine $(A C h)$ synthesis, release, action and breakdown at a cholinergic nerve terminal. AChE acetylcholinesterase, $B C h E$ butyrylcholinesterase, $C h A T$ choline acetyltransferase, $C H T 1$ high-affinity choline transporter-1, $M$ muscarinic receptor, G-protein coupled, $N$ nicotinic receptor, ligand-gated ion channel, VAChT vesicular ACh transporter 


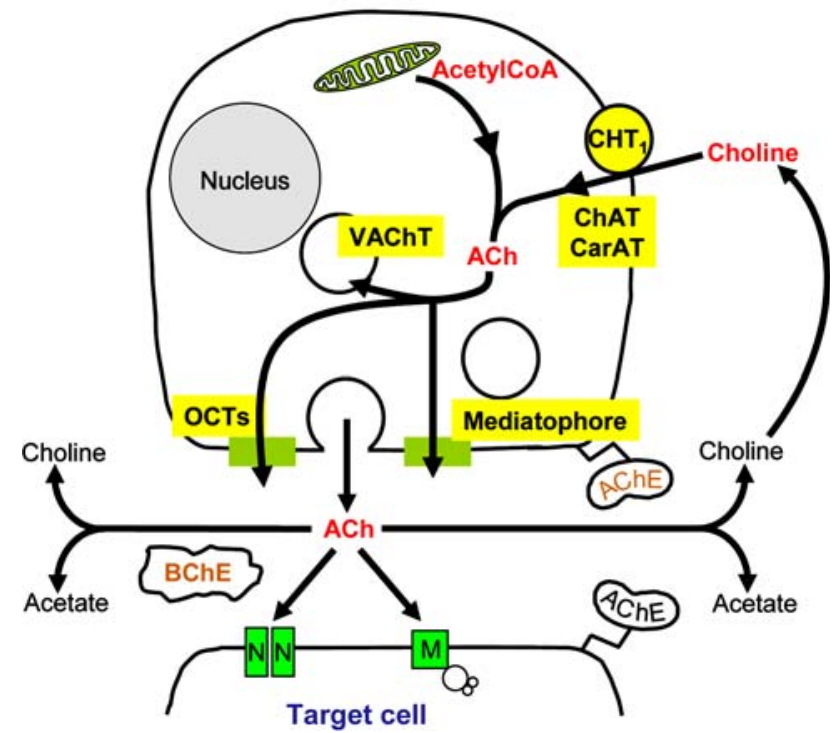

Fig. 4 Summary of recycling pathways of acetylcholine (ACh) synthesis, release, action and breakdown at a non-neuronal cell. CarAT carnitine acetyltransferase, OCTs organic cation transporters. Other abbreviations as in Fig. 3

(Lips et al. 2007a). VAChT and vesicular storage mechanisms for ACh also have not been found regularly in nonneuronal cholinergic cells, implying direct release of $\mathrm{ACh}$ from the cytoplasm instead via exocytosis. Indeed, use of pharmacological inhibitors and siRNA provided evidence for ACh release via plasma membrane-bound polyspecific organic cation transporters (OCT) 1 and 3 (Wessler et al. 2001a), and ACh transport both inside and outside of cells could be directly demonstrated in Xenopus oocytes transfected with either OCT1 or 2 (Lips et al. 2005). These electrogenic transporters are bidirectional and their driving forces are substrate concentration and membrane potential (Koepsell et al. 2007).

A proteolipid called "mediatophore" has been originally described in plasma membranes of the electric organ of the electric ray, torpedo marmorata, where it serves to release ACh either directly from the cytoplasm or by forming the fusion pore between the synaptic vesicle and the plasma membrane (Morel 2003). The mammalian homologue is part of the vacuolar $\mathrm{H}^{+}$-ATPase $\left(\mathrm{V}-\mathrm{ATPase}, \mathrm{V}_{0}\right.$ subunit $\mathrm{c}$ ) that is predominantly targeted to acidic organelles such as lysosomes, endosomes and secretory vesicles (Morel 2003). Mammalian non-neuronal cells transfected with ChAT gain the property to release ACh only when they are co-transfected with this proteolipid and when it is targeted to the plasma membrane (Bloc et al. 1999; Morel 2003). Interestingly, the V-ATPase complex is localized to the plasma membrane in human lung microvascular endothelial cells (Rojas et al. 2004) and rabbit alveolar macrophages (Heming and Bidani 2003), so that "mediatophore" may mediate ACh release from these cells.
Microdialysis experiments on human skin demonstrated that there are other, currently not identified mechanisms of non-neuronal ACh release as well (Schlereth et al. 2006). Once released, ACh can be cleaved by esterases being less specific than AChE, the most prominent one being butyrylcholinesterase (BChE) (Darvesh et al. 2003) (Fig. 4).

\section{Choline transporters in the airway epithelium}

The high-affinity choline transporter CHT1, known from the nervous system, has been localized to the apical membrane of the ciliated cell in the rat trachea, and this finding has been validated by in situ-hybridization, Western blotting of abraded tracheal epithelium, and RT-PCR of tracheal epithelium obtained by laser-assisted microdissection (Pfeil et al. 2003). CHT1-immunolabelling, supported by RT-PCR of scraped epithelium, has also been reported for monkey (rhesus macaques) bronchial epithelium (Proskocil et al. 2004), in this case without further specification of epithelial cell type and subcellular distribution. Functional studies on the bronchial adenocarcinoma cell line A549 also demonstrated a sodium-dependent choline uptake with the characteristics of CHT1 (Kleinzeller et al. 1994). Collectively, these data strongly indicate that there is highaffinity uptake of choline from the airway lining fluid into ciliated cells via a transport system that originally has been thought to be specific for neurons.

These data alone, however, do not explain how choline enters the airway lining fluid at first hand, and how other epithelial cholinergic cells, lacking CHT1, fuel their ACh synthesis. As expected, airway epithelial cells express additional choline transport systems, and they may operate alone or in parallel with CHT1 in specific cell types. A549 cells coexpress at least two choline transport systems, one with CHT1 characteristics $\left(K_{\mathrm{m}}\right.$ of $\left.4 \mu \mathrm{M}\right)$, and a sodiumindependent with a $K_{\mathrm{m}}$ of approximately $44 \mu \mathrm{M}$ that is dependent on a transmembrane $\mathrm{H}^{+}$gradient, is relatively insensitive to hemicholinium-3, and is amiloride sensitive (Kleinzeller et al. 1994).

Choline transporters besides CHT1 can be largely classified into the families of choline-specific transporter-like proteins (CTL family) and polyspecific organic cation transporters (OCT family) (Michel et al. 2006). Members of both families are expressed in the lung. CTL1, the main member of the CTL family (Traiffort et al. 2005), is detected by Western blotting in total human but not mouse lung extracts (Michel et al. 2006), expressed in A549 cells and contributes predominantly to choline uptake in this cell line (Wang et al. 2007; Ishiguro et al. 2008). Its in situ distribution in human airways, as determined by immunohistochemistry or in situ-hybridization, has not been investigated yet. In the rat lung, CTL2 and CTL4 are abundantly 
expressed (Traiffort et al. 2005) but their cellular distribution is unknown.

Among the polyspecific OCT family members, OCT1 and OCT2, but not OCT3, OCTN1 and OCTN2, do transport choline (Busch et al. 1996; Wu et al. 1998, 1999; Sweet et al. 2001). OCT1 is expressed in the mouse, rat and human bronchial epithelium, and immunohistochemistry showed a predominant localization in the apical membrane of ciliated cells but intracellular pools of immunoreactive OCT1 were also detectable (Lips et al. 2005, 2007b; Kummer et al. 2006). At least in rat, OCT1 expression in the airway epithelium is cell type-specific in that OCT1immunoreactivity is selective for ciliated cells but absent in secretory, brush and basal cells (Lips et al. 2005). The specificity of OCT1-immunolabelling was validated by its absence in the respective knockout mouse strain (Kummer et al. 2006). OCT2 is expressed in human and rat but not mouse bronchial epithelium (Lips et al. 2005; Kummer et al. 2006). In human bronchi, OCT2-immunoreactivity is predominant in the luminal membrane of ciliated cells, weakly present in basal cell membranes, and absent from goblet cells (Lips et al. 2005). In OCT1/2 double-knockout mice, tracheal epithelial ACh content is significantly elevated instead of being reduced (Kummer et al. 2006). Thus, although OCT1 and 2 are capable of choline translocation across the plasma membrane, they are obviously not crucial for providing choline for epithelial ACh synthesis.

In conclusion, there is a multiplicity of choline uptake systems in airway epithelial cells with a cell type-specific distribution and a distinct apical versus basolateral polarization. Functional studies indicate prominent roles for CHT1 and CTL1. Further detailed understanding of cellular choline transport in the respiratory epithelium will require detailed investigation of the cellular distribution and intracellular targeting of the members of the CTL family.

\section{ACh synthesis in the airway epithelium}

The presence of both choline acetyltransferase activity as well as of the product ACh itself have been undoubtedly demonstrated within the respiratory epithelium by biochemical methods (Klapproth et al. 1997; Reinheimer et al. 1998; Kummer et al. 2006). Accordingly, the airway epithelium has been reported to be labelled by ChAT antisera (Klapproth et al. 1997; Canning and Fischer 1997; Proskocil et al. 2004). The real identity of the ACh synthesizing enzyme in the individual epithelial cell types; however, is much less clear than it might appear from these apparently coherent pieces of information. First, it has to be noted that there is a great diversity of ChAT variants, all deriving from the same gene. These differences are so marked that antisera directed against ChAT of central nervous system neurons mostly do not react with ChAT produced by peripheral autonomic neurons which rendered a thorough investigation of peripheral cholinergic neurons difficult for a long time and, of course, also that of the non-neuronal cholinergic system.

The mammalian ChAT gene contains three non-coding exons (termed R-, M- and N-exon in the rat and mouse) and, depending on species, 15-16 coding exons (Fig. 5A). The intron-less gene coding for VAChT is inserted between the first two non-coding ChAT exons, i.e. the R- and $\mathrm{N}$-exon, and this peculiar gene structure coding for ChAT and VAChT is designated the "cholinergic gene locus" (Erickson et al. 1994). Alternative transcription starts and splicing result in diversity of mRNAs differing in their $5^{\prime}$-non-coding region. In the rat, five variants are known (Fig. 5a), seven in the mouse and more than six in human (Misawa et al. 1992; Robert and Quirin-Stricker 2001; Ohno et al. 2001).

In the central nervous system, all of these variants are expressed with the M-type ChAT-mRNA usually dominating. We have addressed the question which of these variants is expressed in the rat tracheal epithelium by RT-PCR, and identified solely M-type ChAT-mRNA whereas all five variants were expressed in the spinal cord (Fig. 5b). In scrapings of monkey (rhesus macaques) bronchial epithelium, expression of non-coding exons $\mathrm{N}$ and $\mathrm{S}$ was identified (Proskocil et al. 2004).

In the rat and mouse, all of the mRNA variants of the non-coding region code for the same $69 \mathrm{kDa}$ protein, so that the functional meaning of this diversity might lie in differences in mRNA stability but this issue is not fully understood. In humans, an N-terminally extended $82 \mathrm{kDa}$ ChAT protein variant results from H-type mRNA (Robert and Quirin-Stricker 2001), and this ChAT variant localizes preferentially to the nucleus (Resendes et al. 1999). Different ChAT protein variants can also result from alternative splicing in the coding region. Removal of exons 6-9 results in ChAT of peripheral autonomic neurons (pChAT) as opposed to the more commonly found $69 \mathrm{kDa}$ ChAT (common ChAT = cChAT; Tooyama and Kimura 2000). Performing RT-PCR, we identified full-size cChAT mRNA in the rat tracheal epithelium whereas we were unable to detect pChAT mRNA (Fig. 5c). Thus, at mRNA level the presently available data of the rat trachea show at least a clear dominance, if not even exclusive expression, of a single M-type cChAT mRNA that shall encode for a $69 \mathrm{kDa}$ protein.

We have raised antibodies against a 14 amino acid stretch located in the rat cChAT specific sequence (positions 282-295 of the predicted sequence), and against a peptide of 10 amino acids spanning amino acids 138-141 of exon 5 and amino acids 352-357 of exon 10 which in this sequence shall be unique for pChAT (Pfeil et al. 2004). 


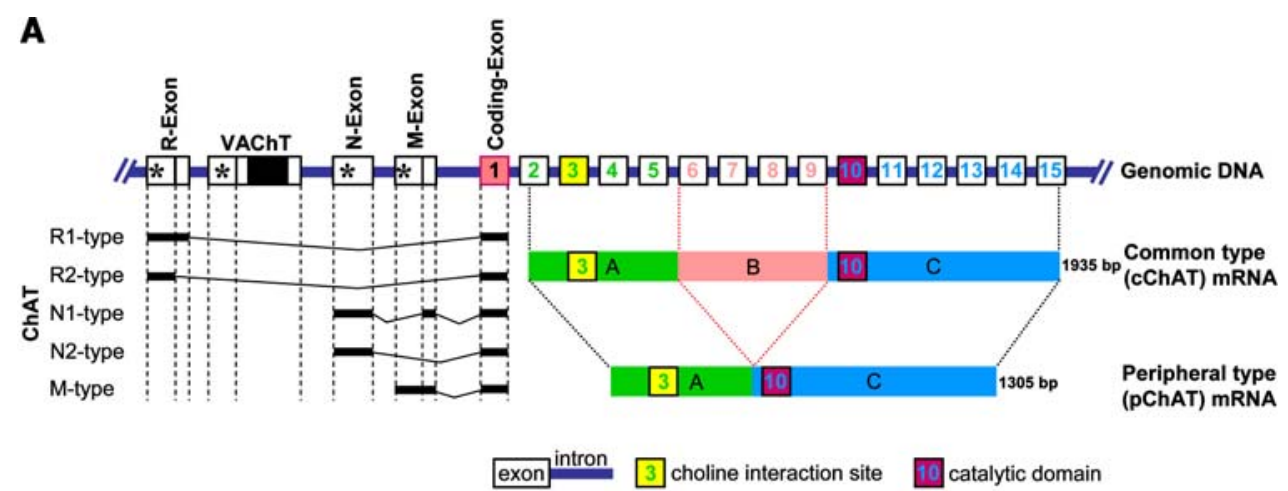

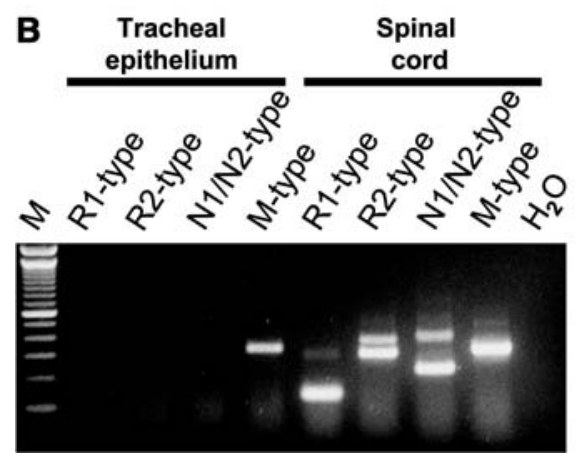

Fig. 5 Choline acetyltransferase $(C h A T)$ variants. a Structure of the "cholinergic gene locus" in the rat. The ChAT gene consists of three non-coding (R, N, M) and 15 coding exons. Use of different transcription starts $\left(^{*}\right)$ and alternative splicing results in 5 variants of ChATmRNA (R1 to $\mathrm{M}$ ) differing in the non-coding region. Alternative splicing in the coding region results in common or peripheral type of ChAT. The intron-less gene of the vesicular acetylcholine transporter (VAChT) is located in the first intron of the ChAT gene. Modified from

In immunohistochemistry, the cChAT-antiserum labelled all epithelial cell types of the rat trachea, and preabsorption of this antibody with the corresponding peptide abolished immunolabelling (Fig. 6a, b). These findings were supported by in situ-hybridization (Fig. 6c, d). In more distal airways, cChAT-immunolabelling of ciliated and secretory cells was generally less intense than in the trachea, whereas endocrine cells and brush cells were particularly cChATimmunolabelled (Fig. 6e, f). Within tracheal ciliated cells, a more intense labelling of the apical cytoplasmatic region was noted, consistent with an earlier report on human bronchi (Klapproth et al. 1997). Thus, in these cells cChAT is located close to the high-affinity uptake system for choline, that is CHT1 (see above), thereby concentrating the entire ACh synthesizing machinery at the apical aspect of the ciliated cell suggesting luminal release.

These data together with the RT-PCR results suggest a rather homogenous expression of a single variant of ChAT, that is ChAT translated from M-type ChAT mRNA, in various airway epithelial cell types. There are, however, quite several data on protein level that point to a more complicated situation. Klapproth and coworkers (1997) reported immuno-

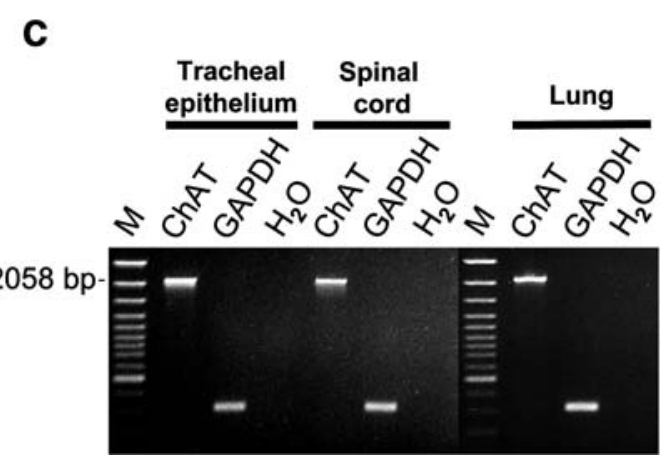

Misawa et al. (1995) and Tooyama and Kimura (2000). b RT-PCR, rat. In abraded rat tracheal epithelium, M-type ChAT mRNA is exclusively expressed whereas all five types of non-coding variants are detected in the spinal cord. c RT-PCR, rat. Full-length common ChAT mRNA is expressed in rat abraded tracheal epithelium and lung. Spinal cord served as positive control. GAPDH glyceraldehyde phosphate dehydrogenase, $\mathrm{M}$ marker, $\mathrm{H}_{2} \mathrm{O}$ control run without template

histochemical ChAT-labelling of human bronchial epithelium with an antibody that recognized 54 and $41 \mathrm{kDa}$ proteins in bronchial epithelial extracts. ChAT protein variants of this molecular weight can not be explained by our current understanding of ChAT mRNA splicing and posttranslational processing. Using our pChAT-antiserum, we obtained strong immunohistochemical labelling of the same cell types that reacted with the cChAT-antiserum in the rat trachea. These data were not supported by RT-PCR. Such a striking discrepancy between clear detection of a pChATimmunoreactive protein and lack of detectable mRNA—or need to use nested RT-PCR - has been reported before also for the rat placenta (Pfeil et al. 2004) and retina (Yasuhara et al. 2004). In neither case, it has been resolved whether this originates from vastly diverse life-times of mRNA and protein, respectively, or from technical problems (false positive protein data or false negative mRNA data). In particular, it shall be taken into account that immunohistochemical labelling may be due to cross reaction with a closely related or even unrelated protein, even if it can be successfully preabsorbed with the corresponding antigen, as recent studies on knockout strains have drastically shown (Moser et al. 2007). 

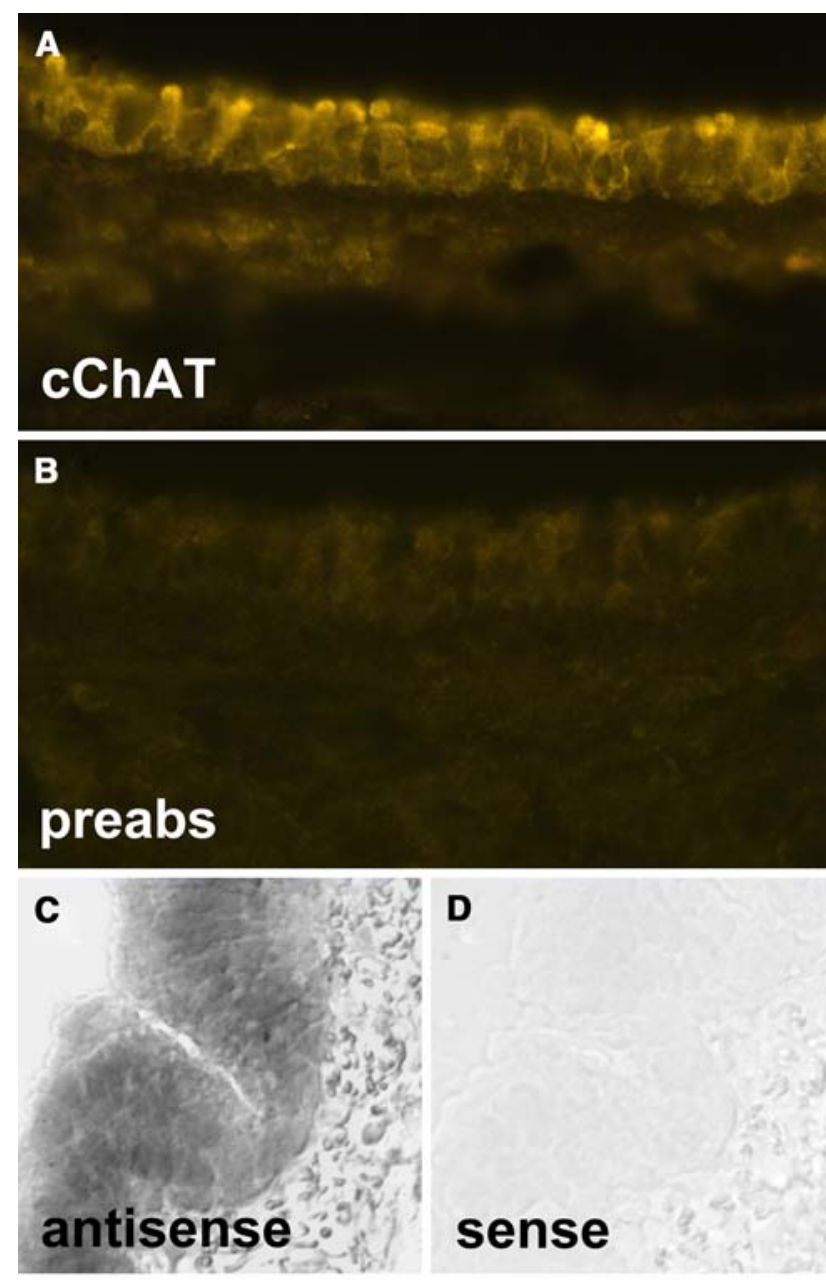

D

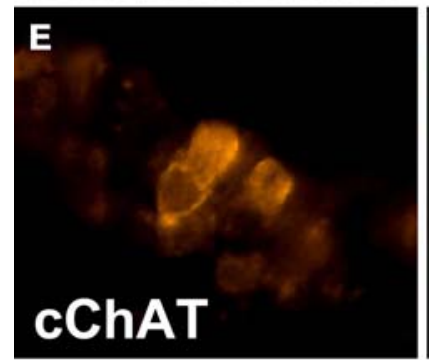

\section{sense}
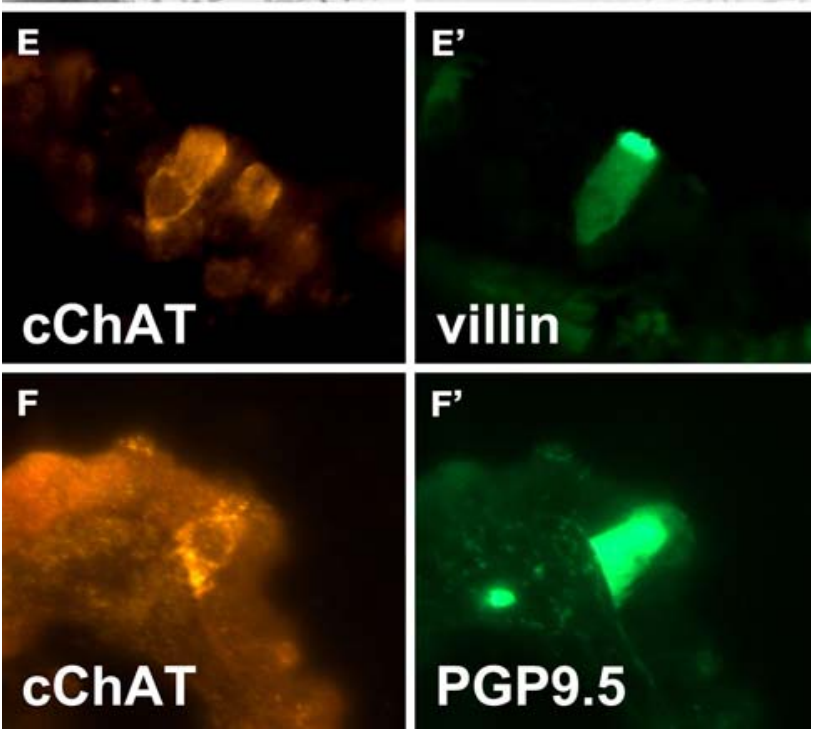

Clear support for ChAT expression in at least a subpopulation of airway epithelial cells comes from a $\mathrm{ChAT}^{\mathrm{BAC}}$ eGFP reporter mouse strain (Tallini et al. 2006). Slender eGFP expressing epithelial cells are situated in the airway epithelium, and these cells are not labelled with a synaptophysin-antibody, a marker for neuroendocrine cells (Tallini
Fig. 6 Common type of choline acetyltransferase $(c C h A T)$ in rat airway epithelium. a An antibody raised against a synthetic peptide unique to cChAT (Pfeil et al. 2004) labels the rat tracheal epithelium. Secretory cells and ciliated cells are identified by their characteristic morphology and are particularly labelled in their supranuclear region. b Corresponding region to a. Preabsorption of the antiserum with cognate peptide results in absence of immunolabelling. $\mathbf{c}$ Rat trachea. In-situ hybridization for cChAT supports immunohistochemistry in that the epithelial layer is labelled throughout. $\mathbf{d}$ Corresponding region to $C$, sense control. e, e' Rat bronchus, double-labelling immunofluorescence. Overall, cChAT-immunolabelling is less intense than in trachea. A solitary distinctly cChAT-immunoreactive cell is identified as brush cell by its immunoreactivity to villin. f, f' Rat bronchus, doublelabelling immunofluorescence. A solitary distinctly cChAT-immunoreactive cell is identified as neuroendocrine by its immunoreactivity to PGP9.5

et al. 2006). Considering that (1) villin-positive brush cells are intensely ChAT-immunoreactive (Fig. 5), (2) exhibit many characteristics of taste cells (Sbarbati and Osculati 2005; Kaske et al. 2007), and (3) taste cells of the tongue express eGFP in this mouse strain (Ogura et al. 2007), it is highly likely that these eGFP expressing cells are airway brush cells.

\section{ACh release machinery in the airway epithelium}

In neurons, VAChT shuffles ACh from the axoplasm into synaptic vesicles (Fig. 2). The intron-less VAChT gene is inserted into the non-coding region of the ChAT gene (Fig. 5), and this peculiar arrangement has been interpreted to orchestrate coordinate expression of ChAT and VAChT (Misawa et al. 1995). In abraded or laser-microdissected airway epithelium, VAChT mRNA is readily detectable (Lips et al. 2005). Notably, it is assumed that expression of VAChT mRNA will not necessarily lead to detectable levels of VAChT protein, because VAChT mRNA is detected in some cells where VAChT protein remained undetectable (Dolezal et al. 2001). In the airway epithelium, VAChTlabelling has been demonstrated by immunohistochemistry in monkey bronchi without further assignment to specific cell types (Proskocil et al. 2004), in secretory cells of the rat trachea (Lips et al. 2005), and neuroepithelial bodies in rat bronchi (Adriaensen et al. 2003). Correspondingly, human small cell lung carcinoma cell lines, derived from airway neuroendocrine cells, express VAChT along with ChAT, and ACh release from these cells is sensitive to vesamicol, a VAChT inhibitor (Song et al. 2003).

Ciliated cells, however, apparently utilize a non-vesicular ACh release mechanism. OCT1 and OCT2 are localized at the apical membrane of ciliated airway epithelial cells, and OCT3 is localized at the basolateral membrane of several cell types in human bronchial epithelium (Lips et al. 2005). Xenopus oocytes transfected with either OCT1 or 2 of rat and human sequence, respectively, indeed translocate 
ACh across the plasma membrane, the direction (release or uptake) being determined by concentration gradient and membrane potential (Lips et al. 2005). In the mouse tracheal epithelium, ACh content is significantly elevated in OCT1/2 double-knockout mice, providing evidence that these polyspecific transporters are involved in epithelial $\mathrm{ACh}$ release in vivo (Kummer et al. 2006). The apical localization of OCT1/2 in airway ciliated cell fits well with the concentration of the high-affinity choline transporter and the ACh synthesizing enzyme ChAT in the same cellular domain, strongly suggesting a complete cycle of ACh synthesis, release and reuptake of choline between the ciliated cell and the luminal airway lining fluid.

The role of OCT3 in the basolateral membrane of various airway epithelial cell types remains unclear at current. Release of ACh from isolated human placental villi is significantly diminished by targeting OCT3 with antisense strategy (Wessler et al. 2001a). In contrast, rat or human OCT3 expressed by Xenopus oocytes do not translocate ACh (Lips et al. 2005). Possibly, OCT3 requires expression of additional proteins to serve as an $\mathrm{ACh}$ transporter.

These polyspecific transporters are the target of numerous drugs which either compete with transport of other cations or block transport without being transported themselves. Relevant for airway pharmacology, nicotine and corticosteroids (corticosterone, fluticasone, budesonide) block ACh release by OCT1 and 2 in vitro (oocyte expression system) (Lips et al. 2005). Thus, inhibition of non-neuronal ACh release is a just recently discovered non-genomic effects of corticosteroids that clearly discriminates non-neuronal from neuronal cholinergic mechanisms in the airways.

The occurrence and distribution of "mediatophore" in the airway epithelium has not been investigated yet.

Collectively, the presently available data suggest the following scenario of ACh release in the respiratory epithelium: vesicular basal release by neuroendocrine and possibly brush cells, vesicular luminal release by secretory cells, and apical concentration- and membrane potential-driven transmembrane release from the cytoplasm of ciliated cells (Fig. 7).

\section{ACh degradation in the airway epithelium}

Neuronal cholinergic transmission is rapidly terminated by enzymatic cleavage of $\mathrm{ACh}$ into acetate and choline by AChE (Fig. 2). This enzyme operates at an extremely high turnover rate, thereby limiting ACh action very effectively both spatially and in time (Rosenberry 1975). The physiological necessity for such a rapid termination of cholinergic transmission is underlined by the very short postnatal survival period (about 2 weeks spontaneously, up to 100 days under special dietary conditions) of AChE gene-deficient mice (Duysen et al. 2002). Besides AChE, there are addi-

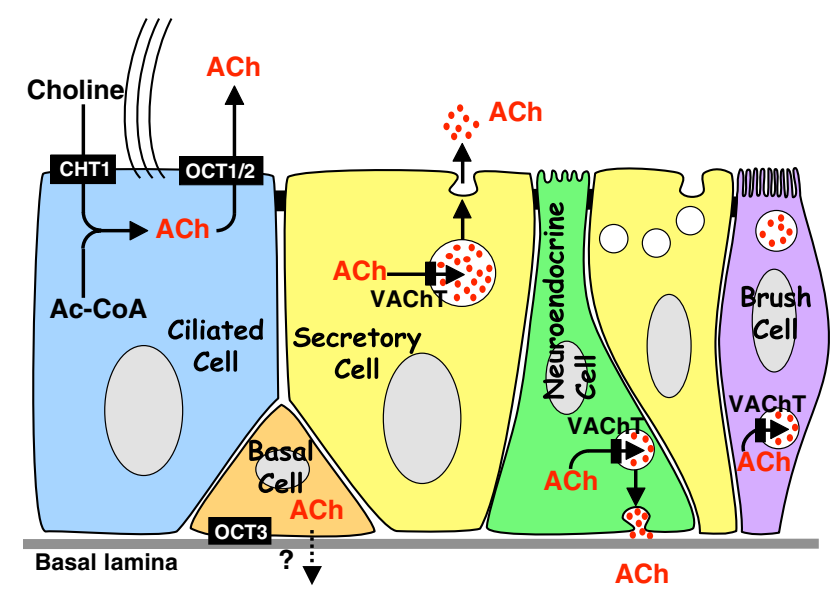

Fig. 7 Schematic drawing of acetylcholine (ACh) release mechanisms from airway surface epithelium cell types. In the brush cell, the direction of vesicular exocytotic release has not been finally identified yet. $C H T 1$ high-affinity choline transporter-1, OCT organic cation transporter, VAChT vesicular acetylcholine transporter. Modified from Kummer and Lips (2006) and extended

tional other, less specific esterases cleaving $\mathrm{ACh}$, the most prominent one being BChE (Fig. 2).

In light of such a rapid extracellular degradation of $\mathrm{ACh}$, the physiological relevance of the epithelial cholinergic system has been questioned because of the following considerations: The amount of ACh generated in the airway epithelium is low compared to that produced by neurons. In FVB mice, for example, epithelial ACh content amounts to only $17 \%$ of that of the entire tracheal wall (Kummer et al. 2006), and the true difference in intracellular concentration between airway epithelial cells and tracheal cholinergic nerve fibres is even manifold higher since the latter may make up about $1 \%$ of tissue volume but contain approximately $80 \%$ of tracheal ACh. Moreover, release of ACh from the dominating epithelial cell type is via transmembrane transport, as reviewed in the preceding chapter, and not via exocytosis that allows for release of approximately 10,000 molecules of ACh per single vesicle. Thus, extracellular concentration of ACh released from epithelial cells is expected to be orders of magnitude lower than that in the surrounding of stimulated cholinergic nerve fibres. This assumption is supported by direct measurements. There are only two successful examples of direct measurement of non-neuronal ACh release into surrounding tissue in vivo (human skin, microdialysis technique; Schlereth et al. 2006, 2007) or into culture medium from freshly isolated biopsies (human placental villi: Wessler et al. 2001a) whereas on most epithelial surfaces, including airway mucosa, only intracellular but not extracellular levels reach concentrations above threshold of detection. Hence, relevant paracrine effects of $\mathrm{ACh}$ indeed have to be questioned in case of the presence of an effective extracellular ACh 
degrading system in the mucosa. Alternatively, it has been suggested that ACh might have intracellular effects by targeting intracellular receptors (Wessler et al. 2001b).

It appears, however, that the epithelial ACh degrading capacity is low, thereby probably enabling paracrine ACh signalling at low concentrations. Scrapings of guinea-pig tracheal epithelium did not hydrolyse ACh (Small et al. 1990), and only a low AChE activity $(117 \mathrm{mU} / \mathrm{mg}$ of epithelial segment) was reported for supernatants of mechanically dissected sheets of porcine tracheal mucosa (Chen et al. 2005) which may also contain subepithelial nerve fibres. Only $40 \%$ $\mathrm{AChE}$ activity was blocked by neostigmine, a potent $\mathrm{AChE}$ inhibitor, suggesting that the majority of this activity is not due to authentic AChE (Chen et al. 2005). Indirect pharmacological approaches operating with various inhibitors and epithelium-intact and epithelium denuded preparations also did not provide evidence for substantial AChE activity in the airway epithelium (Koga et al. 1992; Degano et al. 2001).

One electronmicroscopic histochemical study revealed cholinesterase activity associated with the endoplasmic reticulum located around the basal bodies of cilia in the rat trachea and nasal septum (Graf and Stockinger 1966), and a modified histochemical AChE staining method using increased substrate concentrations resulted in granular labelling of putative neuroendocrine cells in fetal rat airways in vitro (Morikawa et al. 1978). However, subsequent histochemical studies aimed to demonstrate specifically AChE and BChE, respectively, revealed AChE activity of nerve fibres predominantly innervating the airway smooth muscle and BChE activity of the smooth muscle cells themselves (human: Partanen et al. 1982; rat: Small et al. 1990; Ohrui et al. 1991; mouse: Fig. 8).

In conclusion, there is little if any ACh degrading capacity in the airway epithelium which may allow for auto/paracrine effects of small amounts of ACh released by epithelial cells.

\section{Targets and function of the epithelial cholinergic system}

Non-neuronal cholinergic cells are generally assumed to act in an auto/paracrine manner (Wessler et al. 1998). As judged from the subcellular distribution of the ACh releasing machinery, it can be anticipated that secretory and ciliated cells release ACh into the luminal periciliary fluid, whereas endocrine, and possibly basal cells as well, shall secrete ACh basally. Currently, there are no direct clues as to the direction of ACh release from brush cells (Fig. 7).

Luminally released ACh can reach a limited number of cell types only. On one hand, it has access to the luminal aspects of the epithelial cells themselves. On the other, macrophages and to a much lesser extent other cells of the immune system patrol in the mucus layer. Both airway epithelial cells and macrophages carry a variety of muscarinic

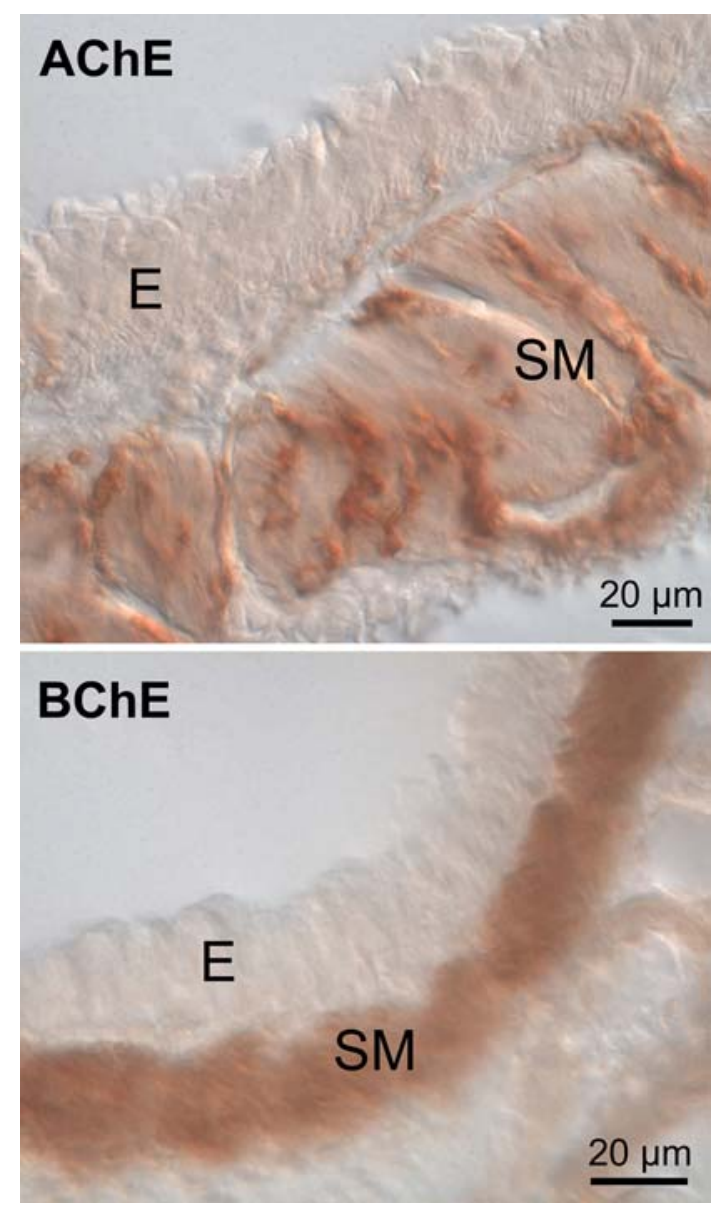

Fig. 8 Histochemical demonstration of acetylcholine degrading enzymes in the mouse trachea. Acetylcholinesterase (AChE) activity is located on nerve fibres penetrating the smooth muscle (SM), which by itself exhibits butyrylcholinesterase $(B C h E)$ activity. $E$ Epithelium

and nicotinic receptors and, hence, are potential targets of locally released ACh. Epithelial cells express muscarinic receptors M1 and M3, and most of the $\alpha$ - and $\beta$-subunits of nAChR (Proskocil et al. 2004; Sekhon et al. 2005; Fig. 9). Our understanding of cell type specific cholinergic effects in the respiratory epithelium would benefit greatly from detailed knowledge of the distribution of cholinergic recep-

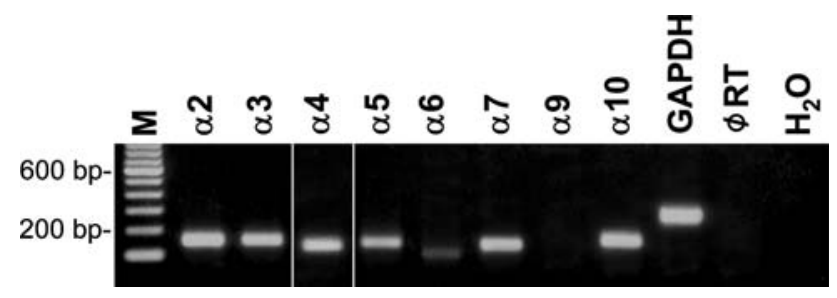

Fig. 9 Expression of multiple nicotinic acetylcholine receptor subunits in the abraded rat tracheal epithelium, RT-PCR. $\alpha$-Subunits 2, 3, 4, 5, 7 and 10 are strongly expressed, subunit $\alpha 6$ is weakly expressed and subunit $\alpha 9$ is missing. GAPDH glyceraldehyde phosphate dehydrogenase, $M$ marker, $\emptyset R T$ control run without reverse transcription, $\mathrm{H}_{2} \mathrm{O}$ control run without template 
tors, both at cellular level (which cell type carries which receptor?) and subcellular level (apical versus basolateral localization of receptors in the cell membrane). Unfortunately, there is only very limited information available since all antibodies directed against nAChR subunits and M1 and M3 receptors tested so far are prone to unspecific staining as indicated by controls performed on respective gene-deficient mice (Herber et al. 2004; Moser et al. 2007; Zarghooni et al. 2007). Hence, it is established that ACh regulates epithelial cell proliferation, mucus secretion, chloride ion secretion, release of GM-CSF and interleukin8 , and stimulates ciliary beat frequency (for review, see Kummer and Lips 2006) but which of these effects may be exerted by ACh released from the epithelium and acting upon apical receptors is not fully resolved yet.

Alveolar macrophages express M3 receptors as well as nAChR subunits (Sato et al. 1998; Matsunaga et al. 2001; Galvis et al. 2006; Biallas et al. 2007; Mikulski et al. 2007). Stimulation of M3 receptors causes cultured bovine alveolar macrophages to release inflammatory cell activity (Sato et al. 1998), whereas stimulation of nAChR has a suppressive effect on alveolar macrophages (Matsunaga et al. 2001; Blanchet et al. 2006) and a general anti-inflammatory effect in the lung (Blanchet et al. 2004; Su et al. 2007). Outside the lung, this nicotinic anti-inflammatory effect on macrophages has been ascribed to nAChR consisting of the $\alpha 7$ subunit (Wang et al. 2003) but independent groups failed to detect this subunit in alveolar macrophages (Matsunaga et al. 2001; Mikulski et al. 2007), and from the presence of subunit expression and pharmacological characteristics an $\alpha 9 / \alpha 10$-subunit composition appears to be most likely. Based upon their localization in the airway lumen, alveolar macrophages are separated from neurally released $\mathrm{ACh}$ and, hence, are a highly likely a target of luminal ACh released from airway epithelial cells (Fig. 10).

Basolaterally released $\mathrm{ACh}$, in principle, has the potential to evoke any of the numerous effects on any cell type of the

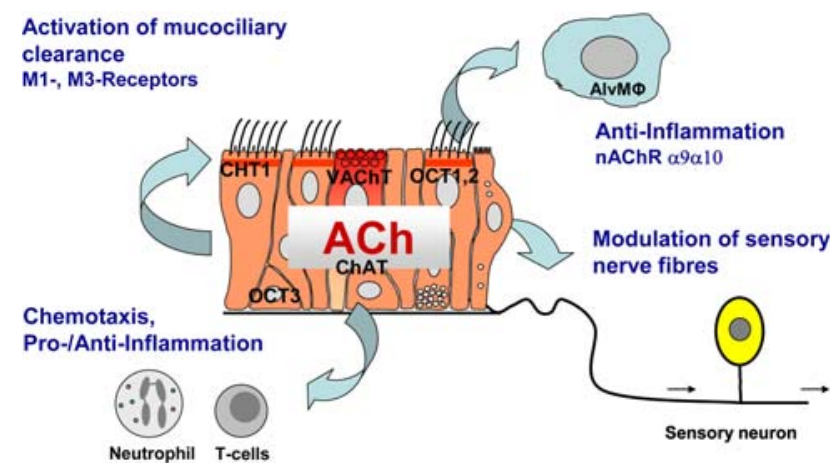

Fig. 10 Scenario of a local auto-/paracrine role of epithelial ACh in regulating various aspects on the innate mucosal defence mechanisms. Pro-proliferative effects both on the epithelium and on subepithelial fibroblasts may occur in parallel airway wall depicted in Fig. 1. A clear distinction between cholinergic effects evoked by epithelial and those evoked by neuronally released ACh is difficult to make and may even be impossible in cases when release occurs from both systems. It has been suggested that epithelial cells of the mouse trachea release ACh upon stimulation with serotonin, thereby causing cholinergic airway constriction (Moffatt et al. 2004). The major finding leading to this conclusion was the sensitivity of the serotonin-induced constriction to atropine, a widely used blocker of cholinergic muscarinic receptors (Moffatt et al. 2004). In mouse bronchi, however, serotonin-induced bronchoconstriction is fully unaffected in M2/M3 receptor doubleknockout mice that are entirely unresponsive to muscarine itself, and this bronchoconstriction is still sensitive to atropine (Struckmann et al. 2003; Kummer et al. 2006). Albeit this study fully confirmed the earlier pharmacological data obtained on trachea it unraveled non-specific effects of atropine and excluded an involvement of epithelial ACh acting upon smooth muscle muscarinic receptors in this set-up. In general, it also has to be considered that the amount of epithelial ACh is by far less than that of neuronally released $\mathrm{ACh}$, and that the smooth muscle layer is equipped with strong cholinolytic activity. Collectively, there is presently no direct evidence for a direct action of epithelially released ACh upon airway smooth muscle or other structures located among smooth muscle cells or even deeper in the airway wall.

While so far there has been no experiment designed that unequivocally allows to discriminating between epithelially and neurally evoked cholinergic effects in the airways, it is plausible to assume that epithelial ACh may preferentially reach those structures that are closest to the epithelium or even penetrate it. Here, subepithelial airway fibroblasts have to be considered as potential target (cf. Fig. 1). In the first line of candidates, however, are cells of the immune system and sensory nerve endings that both are particularly frequent immediately underneath the basement membrane and also are found above it between the epithelial cells. Indeed, vagal sensory airway neurons express nAChR subunits, are sensitive to ACh and nicotine, and are so intimately connected to the epithelium that they respond to inhaled nicotine (Lee et al. 1993, 2007; Gu et al. 2008). Stimulation of such fibres causes local release of neuropeptides and is perceived as irritation, initiating a cough reflex (Jinno et al. 1994; Lee et al. 2007). As such, they are also part of the local innate defence mechanisms.

\section{Role in disease}

Dysregulation of muscarinic receptors is an important feature of frequent airway diseases such as asthma and COPD, and the use of muscarinic antagonists is a major strategy in pharmacological treatment of COPD (Coulson and Fryer 2003; 
Gosens et al. 2006). While the relative contributions of neuronal and non-neuronal ACh in pathomechanisms still have to be worked out, there is agreement that both systems have to be considered and analyzed separately (Kummer and Lips 2006; Gwilt et al. 2007). Based on the seminal finding that ACh levels are increased in the skin biopsies of patients with atopic dermatitis (Wessler et al. 2003) it has been assumed that epithelial ACh may be increased in airway inflammatory diseases as well, thereby contributing to activation of immune cells and to bronchoconstriction (Barnes 2004). Direct measurements, however, point to the opposite direction. The total airway ACh content is reduced in patients suffering from cystic fibrosis (Wessler et al. 2007), and expression of the nonneuronal ACh synthesis and release machinery is down-regulated in acute allergic airway inflammation of rat and mouse (Lips et al. 2007b). Interestingly, administration of keratinocyte growth factor, which is a powerful proactive agent against various injurious stimuli, also down-regulates the pulmonary capacity of non-neuronal ACh production, which has been interpreted as preventing cholinergic over-stimulation (Grau et al. 2007a). Concomitantly, the expression pattern of individual nAChR subunits changes differentially, likely to result in changes in the biological activity of ACh under such conditions (Grau et al. 2007b).

The general stimulatory effect of ACh on epithelial cell proliferation, the presence of $\mathrm{nAChR}$ on airway epithelial cells and the association between smoking and lung cancer very obviously point to a possible link of the intrinsic epithelial cholinergic system and the development of lung cancer. Indeed, small cell lung cancer cells_-originating from neuroendocrine cells of the epithelium - and squamous carcinoma cells synthesize and release ACh, and this serves as an autocrine growth factor, acting both via muscarinic M3 and nAChR receptors (Song et al. 2003, 2007). This important field has been fully reviewed by Song and Spindel (2008). Most recently, three independent groups have demonstrated that variation in a region of $15 \mathrm{q} 25.1$ containing $\mathrm{nAChR}$ genes coding for subunits $\alpha 3, \alpha 5$ and $\beta 4$ contributes to lung cancer risk (Amos et al. 2008; Hung et al. 2008; Thorgeirsson et al. 2008). Besides being activated by ACh, these receptors bind to $\mathrm{N}^{\prime}$-nitrosonornicotine and potential lung carcinogens.

In summary, in inflammatory airways disease the epithelial cholinergic system undergoes plastic changes which either may be part of the pathogenetic process or reflect secondary changes. In lung cancer, however, there is growing evidence that disturbances of this system directly contribute to the development of the disease.

\section{Conclusion}

Among the various airway cell types, there is cell type-specific expression and subcellular distribution of the molecu- lar pathways of ACh release, suggesting both luminal and basolateral release. Although solid direct data discriminating between epithelially and neurally evoked cholinergic effects are very scarce the scenario as known so far strongly suggests a local auto-/paracrine role of epithelial ACh in regulating various aspects on the innate mucosal defence mechanisms, including mucociliary clearance, regulation of macrophage function and modulation of sensory nerve fibre activity (Fig. 10). The proliferative effects of ACh gain importance in ACh receptor disorders conferring susceptibility to lung cancer. Noteworthy, such a role is particularly well supported for small lung cell carcinoma originating from neuroendocrine cells that show a particularly strong expression of cholinergic traits. In allergic inflammatory lung disease, the expression pattern of the non-neuronal cholinergic system is greatly altered but it is currently not clear to which extent this may contribute to the pathogenetic process. The cell type-specific molecular diversity of the ACh synthesis and release machinery is highly likely to imply that non-neuronal ACh release is (a) differently regulated than neuronal ACh release and (b) can be specifically targeted by appropriate drugs. As such the non-neuronal cholinergic system of the airways may emerge as new therapeutic target in treatment of proliferative and inflammatory airway diseases.

Acknowledgments We thank Dr. Maike K. Klein and Ms Alexis D. Wagner for providing Figs. 2 and 6e, f, respectively, which originate from their thesis work conducted in our laboratory, and Ms Karola Michael for skilful assistance in artwork figures. Our studies reviewed here were supported by the DFG.

\section{References}

Adriaensen D, Brouns I, Van Genechten J, Timmermans JP (2003) Functional morphology of pulmonary neuroepithelial bodies: extremely complex airway receptors. Anat Rec A Discov Mol Cell Evol Biol 270:25-40

Adriaensen D, Brouns I, Pintelon I, De Proost I, Timmermans JP (2006) Evidence for a role of neuroepithelial bodies as complex airway sensors: comparison with smooth muscle-associated airway receptors. J Appl Physiol 101:960-970

Amos CI, Wu X, Broderick P, Gorlov IP, Gu J, Eisen T, Dong Q, Zhang Q, Gu X, Vijayakrishnan J, Sullivan K, Matakidou A, Wang Y, Mills G, Doheny K, Tsai YY, Chen WV, Shete S, Spitz MR, Houlston RS (2008) Genome-wide association scan of tag SNPs identifies a susceptibility locus for lung cancer at $15 \mathrm{q} 25.1$. Nat Genet 40:616-622

Apparsundaram S, Ferguson SM, Blakely RD (2001) Molecular cloning and characterization of a murine hemicholinium-3-sensitive choline transporter. Biochem Soc Trans 29:711-716

Barnes PJ (2004) Distribution of receptor targets in the lung. Proc Am Thorac Soc 1:345-351

Belmonte KE (2005) Cholinergic pathways in the lungs and anticholinergic therapy for chronic obstructive pulmonary disease. Proc Am Thorac Soc 2:297-304 discussion 311-312

Biallas S, Wilker S, Lips KS, Kummer W, Grando SA, Padberg W, Grau V (2007) Immunohistochemical detection of nicotinic ace- 
tylcholine receptor subunits alpha9 and alpha10 in rat lung isografts and allografts. Life Sci 80:2286-2289

Blanchet MR, Israël-Assayag E, Cormier Y (2004) Inhibitory effect of nicotine on experimental hypersensitivity pneumonitis in vivo and in vitro. Am J Respir Crit Care Med 169:903-909

Blanchet MR, Israël-Assayag E, Daleau P, Beaulieu MJ, Cormier Y (2006) Dimethyphenylpiperazinium, a nicotinic receptor agonist, downregulates inflammation in monocytes/macrophages through PI3 K and PLC chronic activation. Am J Physiol Lung Cell Mol Physiol 291:L757-L763

Bloc A, Bugnard E, Dunant Y, Falk-Vairant J, Israël M, Loctin F, Roulet E (1999) Acetylcholine synthesis and quantal release reconstituted by transfection of mediatophore and choline acetyltranferase cDNAs. Eur J Neurosci 11:1523-1534

Busch AE, Quester S, Ulzheimer JC, Waldegger S, Gorboulev V, Arndt P, Lang F, Koepsell H (1996) Electrogenic properties and substrate specificity of the polyspecific rat cation transporter rOCT1. J Biol Chem 271:32599-32604

Canning BJ, Fischer A (1997) Localization of cholinergic nerves in lower airways of guinea pigs using antisera to choline acetyltransferase. Am J Physiol 272:L731-L738

Coulson FR, Fryer AD (2003) Muscarinic acetylcholine receptors and airway diseases. Pharmacol Ther 98:59-69

Chen HH, Lin YR, Peng QG, Chan MH (2005) Effects of trichloroethylene and perchloroethylene on muscle contractile responses and epithelial prostaglandin release and acetylcholinesterase activity in swine trachea. Toxicol Sci 83:149-154

Darvesh S, Hopkins DA, Geula C (2003) Neurobiology of butyrylcholinesterase. Nat Rev Neurosci 4:131-138

Degano B, Prévost MC, Berger P, Molimard M, Pontier S, Rami J, Escamilla R (2001) Estradiol decreases the acetylcholine-elicited airway reactivity in ovariectomized rats through an increase in epithelial acetylcholinesterase activity. Am J Respir Crit Care Med 16:1849-1854

Dolezal V, Castell X, Tomasi M, Diebler MF (2001) Stimuli that induce a cholinergic neuronal phenotype of NG108-15 cells upregulate ChAT and VAChT mRNAs but fail to increase VAChT protein. Brain Res Bull 54:363-373

Duysen EG, Stribley JA, Fry DL, Hinrichs SH, Lockridge O (2002) Rescue of the acetylcholinesterase knockout mouse by feeding a liquid diet; phenotype of the adult acetylcholinesterase deficient mouse. Brain Res Dev Brain Res 137:43-54

Erickson JD, Varoqui H, Schäfer MK, Modi W, Diebler MF, Weihe E, Rand J, Eiden LE, Bonner TI, Usdin TB (1994) Functional identification of a vesicular acetylcholine transporter and its expression from a "cholinergic" gene locus. J Biol Chem 269:2192921932

Galvis G, Lips KS, Kummer W (2006) Expression of nicotinic acetylcholine receptors on murine alveolar macrophages. J Mol Neurosci 30:107-108

González-Sistal A, Reigada D, Puchal R, Gómez de Aranda I, Elias M, Marsal J, Solsona C (2007) Ionic dependence of the velocity of release of ATP from permeabilized cholinergic synaptic vesicles. Neuroscience 149:251-255

Gosens R, Zaagsma J, Grootte Bromhaar M, Nelemans A, Meurs H (2004) Acetylcholine: a novel regulator of airway smooth muscle remodelling? Eur J Pharmacol 500:193-201

Gosens R, Zaagsma J, Meurs H, Halayko AJ (2006) Muscarinic receptor signaling in the pathophysiology of asthma and COPD. Respir Res 7:73

Graf J, Stockinger L (1966) Endoplasmatisches Retikulum und Reizleitung im Flimmerepithel. Z Zellforsch Mikrosk Anat 72:184-192

Grau V, Wilker S, Lips KS, Hartmann P, Rose F, Padberg W, Fehrenbach H, Wessler I, Kummer W (2007a) Administration of keratinocyte growth factor down-regulates the pulmonary capacity of acetylcholine production. Int J Biochem Cell Biol 39:1955-1963
Grau V, Wilker S, Hartmann P, Lips KS, Grando SA, Padberg W, Fehrenbach H, Kummer W (2007b) Administration of keratinocyte growth factor (KGF) modulates the pulmonary expression of nicotinic acetylcholine receptor subunits alpha7, alpha9 and alpha10. Life Sci 80:2290-2293

Gu Q, Ni D, Lee LY (2008) Expression of neuronal nicotinic acetylcholine receptors in rat vagal pulmonary sensory neurons. Respir Physiol Neurobiol 16:87-91

Gwilt CR, Donnelly LE, Rogers DF (2007) The non-neuronal cholinergic system in the airways: an unappreciated regulatory role in pulmonary inflammation? Pharmacol Ther 115:208-222

Haag S, Matthiesen S, Juergens UR, Racké K (2008) Muscarinic receptors mediate stimulation of collagen synthesis in human lung fibroblasts. Eur Respir J [Epub ahead of print]

Hansell MM, Moretti RL (1969) Ultrastructure of the mouse tracheal epithelium. J Morphol 128:159-169

Heming TA, Bidani A (2003) Effects of plasmalemmal V-ATPase activity on plasma membrane potential of resident alveolar macrophages. Lung 181:121-135

Herber DL, Severance EG, Cuevas J, Morgan D, Gordon MN (2004) Biochemical and histochemical evidence of nonspecific binding of alpha7nAChR antibodies to mouse brain tissue. J Histochem Cytochem 52:1367-1376

Hung RJ, McKay JD, Gaborieau V, Boffetta P, Hashibe M, Zaridze D, Mukeria A, Szeszenia-Dabrowska N, Lissowska J, Rudnai P, Fabianova E, Mates D, Bencko V, Foretova L, Janout V, Chen C, Goodman G, Field JK, Liloglou T, Xinarianos G, Cassidy A, McLaughlin J, Liu G, Narod S, Krokan HE, Skorpen F, Elvestad MB, Hveem K, Vatten L, Linseisen J, Clavel-Chapelon F, Vineis $\mathrm{P}$, Bueno-de-Mesquita HB, Lund E, Martinez C, Bingham S, Rasmuson T, Hainaut P, Riboli E, Ahrens W, Benhamou S, Lagiou P, Trichopoulos D, Holcátová I, Merletti F, Kjaerheim K, Agudo A, Macfarlane G, Talamini R, Simonato L, Lowry R, Conway DI, Znaor A, Healy C, Zelenika D, Boland A, Delepine M, Foglio M, Lechner D, Matsuda F, Blanche H, Gut I, Heath S, Lathrop M, Brennan P (2008) A susceptibility locus for lung cancer maps to nicotinic acetylcholine receptor subunit genes on $15 \mathrm{q} 25$. Nature 452:633-637

Ishiguro N, Oyabu M, Sato T, Maeda T, Minami H, Tamai I (2008) Decreased biosynthesis of lung surfactant constituent phosphatidylcholine due to inhibition of choline transporter by gefitinib in lung alveolar cells. Pharm Res 25:417-427

Jinno S, Hua XY, Yaksh TL (1994) Nicotine and acetylcholine induce release of calcitonin gene-related peptide from rat trachea. J Appl Physiol 76:1651-1656

Kaske S, Krasteva G, König P, Kummer W, Hofmann T, Gudermann T, Chubanov V (2007) TRPM5, a taste-signaling transient receptor potential ion-channel, is a ubiquitous signaling component in chemosensory cells. BMC Neurosci 8:49

Klapproth H, Reinheimer T, Metzen J, Münch M, Bittinger F, Kirkpatrick CJ, Höhle KD, Schemann M, Racké K, Wessler I (1997) Non-neuronal acetylcholine, a signalling molecule synthezised by surface cells of rat and man. Naunyn Schmiedebergs Arch Pharmacol 355:515-523

Kleinzeller A, Dodia C, Chander A, Fisher AB (1994) Na(+)-dependent and $\mathrm{Na}(+)$-independent systems of choline transport by plasma membrane vesicles of A549 cell line. Am J Physiol 267:C1279-1287

Koepsell H, Lips K, Volk C (2007) Polyspecific organic cation transporters: structure, function, physiological roles, and biopharmaceutical implications. Pharm Res 24:1227-1251

Koga Y, Satoh S, Sodeyama N, Hashimoto Y, Yanagisawa T, Hirshman CA (1992) Role of acetylcholinesterase in airway epithelium-mediated inhibition of acetylcholine-induced contraction of guinea-pig isolated trachea. Eur $\mathrm{J}$ Pharmacol 220:141-146 
Kummer W, Lips KS (2006) Non-neuronal acetylcholine release and its contribution to COPD pathology. Drug Discov Today Dis Mech 3:47-52

Kummer W, Wiegand S, Akinci S, Wessler I, Schinkel AH, Wess J, Koepsell H, Haberberger RV, Lips KS (2006) Role of acetylcholine and polyspecific cation transporters in serotonin-induced bronchoconstriction in the mouse. Respir Res 7:65

Lee LY, Gerhardstein DC, Wang AL, Burki NK (1993) Nicotine is responsible for airway irritation evoked by cigarette smoke inhalation in men. J Appl Physiol 75:1955-1961

Lee LY, Burki NK, Gerhardstein DC, Gu Q, Kou YR, Xu J (2007) Airway irritation and cough evoked by inhaled cigarette smoke: role of neuronal nicotinic acetylcholine receptors. Pulm Pharmacol Ther 20:355-364

Lee RMKW, Forrest JB (1997) Structure and function of cilia. In: Crystal RG, West JB, Weibel ER, Barnes PJ (eds) The Lung. Scientific Foundations, vol 1. Lippincott-Raven, Philadelphia, pp 459-478

Linnoila RI (2006) Functional facets of the pulmonary neuroendocrine system. Lab Invest 86:425-444

Lips KS, Volk C, Schmitt BM, Pfeil U, Arndt P, Miska D, Ermert L, Kummer W, Koepsell H (2005) Polyspecific cation transporters mediate luminal release of acetylcholine from bronchial epithelium. Am J Respir Cell Mol Biol 33:79-88

Lips KS, Wunsch J, Zarghooni S, Bschleipfer T, Schukowski K, Weidner W, Wessler I, Schwantes U, Koepsell H, Kummer W (2007a) Acetylcholine and molecular components of its synthesis and release machinery in the urothelium. Eur Urol 51:1042-1053

Lips KS, Lührmann A, Tschernig T, Stoeger T, Alessandrini F, Grau V, Haberberger RV, Koepsell H, Pabst R, Kummer W (2007b) Down-regulation of the non-neuronal acetylcholine synthesis and release machinery in acute allergic airway inflammation of rat and mouse. Life Sci 80:2263-2269

Lukas RJ, Changeux JP, Le Novère N, Albuquerque EX, Balfour DJ, Berg DK, Bertrand D, Chiappinelli VA, Clarke PB, Collins AC, Dani JA, Grady SR, Kellar KJ, Lindstrom JM, Marks MJ, Quik M, Taylor PW, Wonnacott S (1999) International Union of Pharmacology. XX. Current status of the nomenclature for nicotinic acetylcholine receptors and their subunits. Pharmacol Rev 51:397-401

Matsunaga K, Klein TW, Friedman H, Yamamoto Y (2001) Involvement of nicotinic acetylcholine receptors in suppression of antimicrobial activity and cytokine responses of alveolar macrophages to Legionella pneumophila infection by nicotine. J Immunol 167:6518-6524

Merigo F, Benati D, Di Chio M, Osculati F, Sbarbati A (2007) Secretory cells of the airway express molecules of the chemoreceptive cascade. Cell Tissue Res 327:231-247

Metzen J, Bittinger F, Kirkpatrick CJ, Kilbinger H, Wessler I (2003) Proliferative effect of acetylcholine on rat trachea epithelial cells is mediated by nicotinic receptors and muscarinic receptors of the M1-subtype. Life Sci 72:2075-2080

Michel V, Yuan Z, Ramsubir S, Bakovic M (2006) Choline transport for phospholipid synthesis. Exp Biol Med (Maywood) 231:490504

Mikulski Z, Hartmann P, Lips KS, Biallas S, Pfeil U, Grando SA, Grau V, Kummer W (2007) Nicotinic receptors on rat alveolar macrophages dampen ATP-induced increase in cytosolic calcium concentration. Am J Resp Crit Care Med 175:A470

Misawa H, Ishii K, Deguchi T (1992) Gene expression of mouse choline acetyltransferase. Alternative splicing and identification of a highly active promoter region. J Biol Chem 267:20392-20399

Misawa H, Takahashi R, Deguchi T (1995) Coordinate expression of vesicular acetylcholine transporter and choline acetyltransferase in sympathetic superior cervical neurones. Neuroreport 6:965968
Moffatt JD, Cocks TM, Page CP (2004) Role of the epithelium and acetylcholine in mediating the contraction to 5-hydroxytryptamine in the mouse isolated trachea. Br J Pharmacol 141:1159-1166

Morel N (2003) Neurotransmitter release: the dark side of the vacuolar- $\mathrm{H}^{+}$ATPase. Biol Cell 95:453-457

Morikawa Y, Donahoe PK, Hendren WH (1978) Cholinergic nerve development of fetal lung in vitro. J Pediatr Surg 13:653-661

Moser N, Mechawar N, Jones I, Gochberg-Sarver A, Orr-Urtreger A, Plomann M, Salas R, Molles B, Marubio L, Roth U, Maskos U, Winzer-Serhan U, Bourgeois JP, Le Sourd AM, De Biasi M, Schröder H, Lindstrom J, Maelicke A, Changeux JP, Wevers A (2007) Evaluating the suitability of nicotinic acetylcholine receptor antibodies for standard immunodetection procedures. J Neurochem 102:479-492

Neptune ER, Podowski M, Calvi C, Cho JH, Tuder R, Linnoila RI, Tsai MJ, Dietz HC (2008) Targeted disruption of NeuroD, a proneural bHLH factor, impairs distal lung formation and neuroendocrine morphology in the neonatal lung. J Biol Chem [Epub ahead of print]

Ogura T, Margolskee RF, Tallini YN, Shui B, Kotlikoff MI, Lin W (2007) Immuno-localization of vesicular acetylcholine transporter in mouse taste cells and adjacent nerve fibers: indication of acetylcholine release. Cell Tissue Res 330:17-28

Ohno K, Tsujino A, Brengman JM, Harper CM, Bajzer Z, Udd B, Beyring R, Robb S, Kirkham FJ, Engel AG (2001) Choline acetyltransferase mutations cause myasthenic syndrome associated with episodic apnea in humans. Proc Natl Acad Sci USA 98:20172022

Ohrui T, Sekizawa K, Yamauchi K, Ohkawara Y, Nakazawa H, Aikawa T, Sasaki H, Takishima T (1991) Chemical oxidant potentiates electrically and acetylcholine-induced contraction in rat trachea: possible involvement of cholinesterase inhibition. J Pharmacol Exp Ther 259:371-376

Okuda T, Haga T, Kanai Y, Endou H, Ishihara T, Katsura I (2000) Identification and characterization of the high-affinity choline transporter. Nat Neurosci 3:120-125

Oliveira MJ, Pereira AS, Guimarães L, Grande NR, de Sá CM, Aguas AP (2003) Zonation of ciliated cells on the epithelium of the rat trachea. Lung 181:275-282

Osculati F, Bentivoglio M, Castellucci M, Cinti S, Zancanaro C, Sbarbati A (2007) The solitary chemosensory cells and the diffuse chemosensory system of the airway. Eur J Histochem 51(Suppl 1):65-72

Ostrowski LE, Yin W, Diggs PS, Rogers TD, O’Neal WK, Grubb BR (2007) Expression of CFTR from a ciliated cell-specific promoter is ineffective at correcting nasal potential difference in CF mice. Gene Ther 14:1492-1501

Parsons SM (2000) Transport mechanisms in acetylcholine and monoamine storage. FASEB J 14:2423-2434

Partanen M, Laitinen A, Hervonen A, Toivanen M, Laitinen LA (1982) Catecholamine- and acetylcholinesterase-containing nerves in human lower respiratory tract. Histochemistry 76:175-188

Pavelka M, Ronge HR, Stockinger G (1976) Vergleichende Untersuchungen am Trachealepithel verschiedener Säuger. Acta Anat (Basel) 94:262-282

Perl AK, Wert SE, Nagy A, Lobe CG, Whitsett JA (2002) Early restriction of peripheral and proximal cell lineages during formation of the lung. Proc Natl Acad Sci USA 99:10482-10487

Pfeil U, Lips KS, Eberling L, Grau V, Haberberger RV, Kummer W (2003) Expression of the high-affinity choline transporter, CHT1, in the rat trachea. Am J Respir Cell Mol Biol 28:473-477

Pfeil U, Vollerthun R, Kummer W, Lips KS (2004) Expression of the cholinergic gene locus in the rat placenta. Histochem Cell Biol 122:121-130

Plopper CG, Hill LH, Mariassy AT (1980) Ultrastructure of the nonciliated bronchiolar epithelial (Clara) cell of mammalian lung. III. A 
study of man with comparison of 15 mammalian species. Exp Lung Res 1:171-180

Profita M, Bonanno A, Siena L, Ferraro M, Montalbano AM, Pompeo F, Riccobono L, Pieper MP, Gjomarkaj M (2008) Acetylcholine mediates the release of IL-8 in human bronchial epithelial cells by a NFkB/ ERK-dependent mechanism. Eur J Pharmacol 582:145-153

Proskocil BJ, Sekhon HS, Jia Y, Savchenko V, Blakely RD, Lindstrom J, Spindel ER (2004) Acetylcholine is an autocrine or paracrine hormone synthesized and secreted by airway bronchial epithelial cells. Endocrinology 145:2498-2506

Puchelle E, Gaillard D, Ploton D, Hinnrasky J, Fuchey C, Boutterin MC, Jacquot J, Dreyer D, Pavirani A, Dalemans W (1992) Differential localization of the cystic fibrosis transmembrane conductance regulator in normal and cystic fibrosis airway epithelium. Am J Respir Cell Mol Biol 7:485-491

Reigada D, Díez-Pérez I, Gorostiza P, Verdaguer A, Gómez de Aranda I, Pineda O, Vilarrasa J, Marsal J, Blasi J, Aleu J, Solsona C (2003) Control of neurotransmitter release by an internal gel matrix in synaptic vesicles. Proc Natl Acad Sci USA 100:3485-3490

Reinheimer T, Münch M, Bittinger F, Racké K, Kirkpatrick CJ, Wessler I (1998) Glucocorticoids mediate reduction of epithelial acetylcholine content in the airways of rats and humans. Eur $\mathbf{J}$ Pharmacol 349:277-284

Resendes MC, Dobransky T, Ferguson SS, Rylett RJ (1999) Nuclear localization of the $82-\mathrm{kDa}$ form of human choline acetyltransferase. J Biol Chem 274:19417-19421

Robbins RA, Rennart SI (1997) Biology of airway epithelial cells. In: Crystal RG, West JB, Weibel ER (eds) The lung. Scientific foundations, vol 1. Lippincott-Raven, Philadelphia, pp 445-447

Robert I, Quirin-Stricker C (2001) A novel untranslated 'exon H' of the human choline acetyltransferase gene in placenta. J Neurochem 79:9-16

Rojas JD, Sennoune SR, Maiti D, Martínez GM, Bakunts K, Wesson DE, Martínez-Zaguilán R (2004) Plasmalemmal V-H+H -ATPases regulate intracellular $\mathrm{pH}$ in human lung microvascular endothelial cells. Biochem Biophys Res Commun 320:1123-1132

Rosenberry TL (1975) Acetylcholinesterase. Adv Enzymol Relat Areas Mol Biol 43:103-218

Sato E, Koyama S, Okubo Y, Kubo K, Sekiguchi M (1998) Acetylcholine stimulates alveolar macrophages to release inflammatory cell chemotactic activity. Am J Physiol 274:L970-979

Sbarbati A, Osculati F (2005) The taste cell-related diffuse chemosensory system. Prog Neurobiol 75:295-307

Sbarbati A, Osculati F (2006) Allelochemical communication in vertebrates: kairomones, allomones and synomones. Cells Tissues Organs 183:206-219

Schlereth T, Birklein F, an Haack K, Schiffmann S, Kilbinger H, Kirkpatrick CJ, Wessler I (2006) In vivo release of non-neuronal acetylcholine from the human skin as measured by dermal microdialysis: effect of botulinum toxin. $\mathrm{Br} \mathrm{J}$ Pharmacol 147:183-187

Schlereth T, Schönefeld S, Birklein F, Kirkpatrick CJ, Wessler I (2007) In vivo release of non-neuronal acetylcholine from human skin by dermal microdialysis: effects of sunlight, UV-A and tactile stimulus. Life Sci 80:2239-2242

Sekhon HS, Song P, Jia Y, Lindstrom J, Spindel ER (2005) Expression of lynx 1 in developing lung and its modulation by prenatal nicotine exposure. Cell Tissue Res 320:287-297

Small RC, Good DM, Dixon JS, Kennedy I (1990) The effects of epithelium removal on the actions of cholinomimetic drugs in opened segments and perfused tubular preparations of guinea-pig trachea. Br J Pharmacol 100:516-522

Song P, Spindel ER (2008) Basic and clinical aspects of non-neuronal acetylcholine: expression of non-neuronal acetylcholine in lung cancer provides a new target for cancer therapy. J Pharmacol Sci 106:180-185
Song P, Sekhon HS, Jia Y, Keller JA, Blusztajn JK, Mark GP, Spindel ER (2003) Acetylcholine is synthesized by and acts as an autocrine growth factor for small cell lung carcinoma. Cancer Res 63:214-221

Song P, Sekhon HS, Lu A, Arredondo J, Sauer D, Gravett C, Mark GP, Grando SA, Spindel ER (2007) M3 muscarinic receptor antagonists inhibit small cell lung carcinoma growth and mitogen-activated protein kinase phosphorylation induced by acetylcholine secretion. Cancer Res 67:3936-3944

Struckmann N, Schwering S, Wiegand S, Gschnell A, Yamada M, Kummer W, Wess J, Haberberger RV (2003) Role of muscarinic receptor subtypes in the constriction of peripheral airways: studies on receptor-deficient mice. Mol Pharmacol 64:14441451

Su X, Lee JW, Matthay ZA, Mednick G, Uchida T, Fang X, Gupta N, Matthay MA (2007) Activation of the alpha7 nAChR reduces acid-induced acute lung injury in mice and rats. Am J Respir Cell Mol Biol 37:186-192

Sweet DH, Miller DS, Pritchard JB (2001) Ventricular choline transport: a role for organic cation transporter 2 expressed in choroid plexus. J Biol Chem 276:41611-41619

Tallini YN, Shui B, Greene KS, Deng KY, Doran R, Fisher PJ, Zipfel W, Kotlikoff MI (2006) BAC transgenic mice express enhanced green fluorescent protein in central and peripheral cholinergic neurons. Physiol Genomics 27:391-397

Thorgeirsson TE, Geller F, Sulem P, Rafnar T, Wiste A, Magnusson KP, Manolescu A, Thorleifsson G, Stefansson H, Ingason A, Stacey SN, Bergthorsson JT, Thorlacius S, Gudmundsson J, Jonsson T, Jakobsdottir M, Saemundsdottir J, Olafsdottir O, Gudmundsson LJ, Bjornsdottir G, Kristjansson K, Skuladottir H, Isaksson HJ, Gudbjartsson T, Jones GT, Mueller T, Gottsäter A, Flex A, Aben KK, de Vegt F, Mulders PF, Isla D, Vidal MJ, Asin L, Saez B, Murillo L, Blondal T, Kolbeinsson H, Stefansson JG, Hansdottir I, Runarsdottir V, Pola R, Lindblad B, van Rij AM, Dieplinger B, Haltmayer M, Mayordomo JI, Kiemeney LA, Matthiasson SE, Oskarsson H, Tyrfingsson T, Gudbjartsson DF, Gulcher JR, Jonsson S, Thorsteinsdottir U, Kong A, Stefansson K (2008) A variant associated with nicotine dependence, lung cancer and peripheral arterial disease. Nature 452:638-642

Tooyama I, Kimura H (2000) A protein encoded by an alternative splice variant of choline acetyltransferase mRNA is localized preferentially in peripheral nerve cells and fibers. J Chem Neuroanat 17:217-226

Traiffort E, Ruat M, O'Regan S, Meunier FM (2005) Molecular characterization of the family of choline transporter-like proteins and their splice variants. J Neurochem 92:1116-1125

Tucek S (1982) The synthesis of acetylcholine in skeletal muscles of the rat. J Physiol 322:53-69

Wang H, Yu M, Ochani M, Amella CA, Tanovic M, Susarla S, Li JH, Wang H, Yang H, Ulloa L, Al-Abed Y, Czura CJ, Tracey KJ (2003) Nicotinic acetylcholine receptor alpha7 subunit is an essential regulator of inflammation. Nature 421:384-388

Wang T, Li J, Chen F, Zhao Y, He X, Wan D, Gu J (2007) Choline transporters in human lung adenocarcinoma: expression and functional implications. Acta Biochim Biophys Sin (Shanghai) 39:668-674

Wess J, Eglen RM, Gautam D (2007) Muscarinic acetylcholine receptors: mutant mice provide new insights for drug development. Nat Rev Drug Discov 6:721-733

Wessler I, Kirkpatrick CJ, Racké K (1998) Non-neuronal acetylcholine, a locally acting molecule, widely distributed in biological systems: expression and function in humans. Pharmacol Ther 77:59-79

Wessler I, Kirkpatrick CJ, Racké K (1999) The cholinergic 'pitfall': acetylcholine, a universal cell molecule in biological systems, including humans. Clin Exp Pharmacol Physiol 26:198-205 
Wessler I, Roth E, Deutsch C, Brockerhoff P, Bittinger F, Kirkpatrick CJ, Kilbinger H (2001a) Release of non-neuronal acetylcholine from the isolated human placenta is mediated by organic cation transporters. Br J Pharmacol 134:951-956

Wessler I, Kilbinger H, Bittinger F, Kirkpatrick CJ (2001b) The biological role of non-neuronal acetylcholine in plants and humans. Jpn J Pharmacol 85:2-10

Wessler I, Reinheimer T, Kilbinger H, Bittinger F, Kirkpatrick CJ, Saloga J, Knop J (2003) Increased acetylcholine levels in skin biopsies of patients with atopic dermatitis. Life Sci 72:2169-2172

Wessler I, Bittinger F, Kamin W, Zepp F, Meyer E, Schad A, Kirkpatrick CJ (2007) Dysfunction of the non-neuronal cholinergic system in the airways and blood cells of patients with cystic fibrosis. Life Sci 80:2253-2258

Wu X, Prasad PD, Leibach FH, Ganapathy V (1998) cDNA sequence, transport function, and genomic organization of human OCTN2, a new member of the organic cation transporter family. Biochem Biophys Res Commun 246:589-595
Wu X, Huang W, Prasad PD, Seth P, Rajan DP, Leibach FH, Chen J, Conway SJ, Ganapathy V (1999) Functional characteristics and tissue distribution pattern of organic cation transporter 2 (OCTN2), an organic cation/carnitine transporter. J Pharmacol Exp Ther 290:1482-1492

Wu JV, Krouse ME, Wine JJ (2007) Acinar origin of CFTR-dependent airway submucosal gland fluid secretion. Am J Physiol Lung Cell Mol Physiol 292:L304-L311

Yasuhara O, Aimi Y, Shibano A, Matsuo A, Bellier JP, Park M, Tooyama I, Kimura H (2004) Innervation of rat iris by trigeminal and ciliary neurons expressing pChAT, a novel splice variant of choline acetyltransferase. J Comp Neurol 472:232-245

Zarghooni S, Wunsch J, Bodenbenner M, Brüggmann D, Grando SA, Schwantes U, Wess J, Kummer W, Lips KS (2007) Expression of muscarinic and nicotinic acetylcholine receptors in the mouse urothelium. Life Sci 80:2 